\title{
密閉熱サイフォン型冷中性子源の非連続 モデルによる熱力学的考察
}

\author{
河合武 \\ 京都大学原子奸実験所 大阪府泉南郡熊取町
}

(1988 年 9 月 5 日受理)

Thermodynamic Considerations of a Closed-thermosiphon Type Cold

Neutron Source by a Discontinuous Model

Takeshi KawAI

Research Reactor Institute, Kyoto University, Kumatori-cho, Sennan-gun, Osaka 590-04

(Received September 5, 1988)

\section{Synopsis :}

A fundamental consideration of a closed-thermosiphon type cold neutron source (CNS) has been presented on the basis of the non-equilibrium thermodynamics. In order to simplify the treatment, a discontinuous thermodynamic model consisting of two large sub-systems connected by a small transport sub-system is employed. The analyses are especially concentrated in the self-regulation property, that is, the amount of liquid hydrogen in the moderator cell can be kept almost constant against thermal disturbances from reactor output fluctuations. It is shown that this property results from a thermodynamic process producing an entropy of a total system by a temperature increment in which an evaporation in one sub-system is compensated by a liquefaction in the other sub-system linked together by a common quantity of latent heat.

\section{1. 緒言}

冷中性子はふつう, ベリリュウムのブラッグの切断 エネルギーに相当する波長 $4 \AA$ 迀上の中性子をいう。 冷中性子は, 生体高分子や非晶体等の相変化における 臨界点近傍の摇らぎや長周期構造を調べるのに適して いる。最近, 基礎物理の分野で極冷中性子や超冷中性 子が中性子の電気双極子能率や寿命, 干涉等の研究に 用いられるようになった。極冷中性子や超泠中性子も 冷中性子からつくられる。しかし, 通常の研究炉で は, 冷中性子の強度は全中性子束の $1 \sim 2 \%$ ある。 したがって，泠中性子束を増強することが望ましい。 この目的のためには, ふつう熱中性子を, 冷減速材で ある極低温に冷却された液体水素等の層に通して散乱 させることにより冷中性子を取り出す冷中性子源設備 が用いられる。

冷中性子源は泠中性子束を安定に供給する必要があ り，そのためには泠減速材である液体水素または重水
素が泠減速材槽中に必要十分な量安定に貯溜されてい ることが必要である。最近設置された泠中性子源は密 閉熱サイフォン型が多いが1)，この型の冷中性子源に おいては, 原子炬の出力変動等により泠減速材槽への 熱負荷が変動しても冷減速材槽内の液面が安定に保た れる。これは，負荷が増加したとき，椧減速材である 液体水素の蒸発により系の圧力が増加し, 水素の沸点 が上昇することにより潜熱が小さくなること，ならび に温度上昇により凝縮器の液化能力が増加するためで ある。この性質を, 液量が熱負荷の変動下においても 一定に保たれるという意味で自己平衡性という。わ れわれは低温水素循環系を用いてこのことを明らかに $\iota^{2,3)}$, 我が国では最初の原子炉冷中性子源である KUR 冷中性子源にも応用して, 安定な椧中性子束を 得ることができた

Fig. 1 (a) に密閉熱サイフォン型冷中性子源の概念 図を示す。主要部は冷減速材槽，冷減速材輸送管およ び凝縮器からなる水素低温系であり，水素系は貯槽を

Vol. 23 No. 6 (1988) 


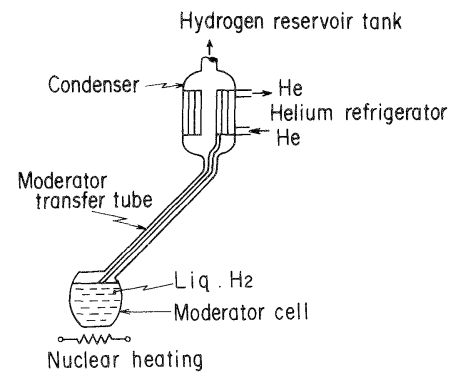

a: Hydrogen cold system

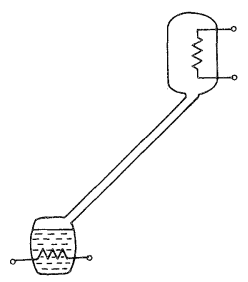

$b$ : Model for simulation

Fig. 1 Schema of a closed-thermosiphon type cold neutron source.

含めて密閉系であるが，ここでは冷減速材槽に液体水 素が十分貯溜されている定常状態を取り扱うので，水 素低温系を密閉系として扱う。密閉熱サイフォン型冷 中性子源の熱力学過程は, 冷減速材槽での核発熱吸収 による液体水素の蒸発過程, 水素蒸気の泠減速材輸送 管における輸送過程, 凝縮器での熱の放出による再液 化過程, そして液体水素の泠減速材槽への輸送過程で ある。冷減速材輸送管は実際には蒝気管の内部に液管 がある二重管の構造となっているが，ここでは 1 本の パイプからなるものとする。液は重力により流下し， 蒸気は密度の差により上昇する。したがって, 系は明 らかに非平衡であるので, 冷減速材槽と凝縮器を部分 系と寸る非連続系として取り扱う。冷減速材槽と凝縮 器では水素の蒸発と液化が起こっているので, 相変化 として扱う。輸送管部における相変化は, 核発熱の量 が小さいので無視する。

本報告では，水素低温系を非平衡熱力学により解析 し, 密閉熱サイフォン型冷中性子源の特性である自己 平衡性の条件ならびに熱力学的意味を導く。

\section{2. 非平衡熱力学による解析}

\section{1 密閉非連綪系のモデル化}

系全体として定常状態にある密閉熱サイフォン型冷

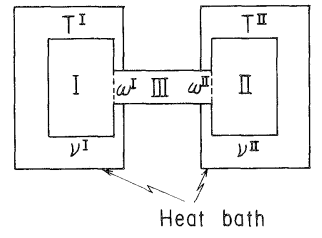

a: Discontinuous thermodynamic model

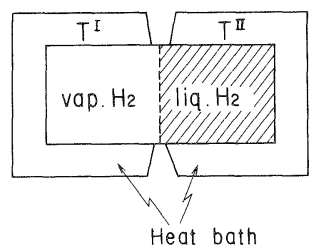

b: Idealyzed thermosyphon model

Fig. 2 Thermodynamic models of the hydrogen cold system and an idealized thermosiphon.

中性子源を Fig. 1 (b) に示す。泠減速材槽は核発熱を 吸収し一定温度 $T$ I に, 凝縮器は温度 $T$ II に保たれ ている。冷減速材輸送管は泠減速材槽に近い部分の核 発熱を無視すると周囲と断熱されているので, 冷減速 材槽と同じ温度に保たれている。したがって，本系は 少なくとも二つの部分系からなる非連続系として取り 扱われるべきであり，さらにその接続部の輸送管部 は，第三の部分系と見なすと便利である。冷減速材槽 には常に液体水素があり, 凝縮器では水素が液化して いる。これにより水素の関与する過程は，部分系 I, II における蒸発，液化と，IIIにおける蒸気と液の輸 送のみと考えることができる。以上の結果，系を模型 化すると Fig. 2 (a)のようになる。すなわち, 系は二 つの部分系, I, II が小さい容量の部分系 III によっ て連結され，I，II の状態変数が III において非連続 的に変化するものとする。この部分系 I, II は，それ ぞれ無限容量の定温槽（ $T$ I,$T$ II $)$ に接していると しよう。系の各成分を $k$ で表すと， $k=1,2$ となり， $k=1$ を液相の水素, 2 を気相の水素とする。部分系 I，II では蒸発，液化が起こっているとするが，部 分系 III では気相-液相間の変化は起こらないものと する。 $\omega^{\alpha}$ は相隣る部分系との境界を， $\nu^{\alpha}$ はとの他の 境界を表すものとする。このような系の定常状態につ いて論じる。

\section{2 保存方程式}

この系では全系としても各部分系としてもその境界 低温工学 
は固定されているので, 系の示量変数 $F(t)$ の時間微 分は示強変数 $f(r, t)$ を用いて,

$$
d F(t) / d t=\int\{\delta f(r, t) / \delta t\} d V
$$

で与えられる7。したがって，部分系I，II，IIIを $\alpha$ で代表すると， $\alpha$ にお拈る成分 $k$ の物質収支は，

$$
\begin{aligned}
d M_{k}^{\alpha} / d t= & -\oint_{\Omega^{\alpha} \rho_{k} v_{k} d \Omega^{\alpha}} \\
& +\int_{V^{\alpha} J_{j}^{\alpha} d V^{\alpha}}
\end{aligned}
$$

で表される。ここで, $M_{k}{ }^{\alpha}$ は部分系 $\alpha$ の成分 $k$ の質 量, $\rho_{k}$ は成分 $k$ の密度, $v_{k}$ は成分 $k$ の速度, $J_{j}$ は相 変化の速度，Vは体積をあらわす。

Fig. 2 (a)に示すように, 各部分系の表面 $\Omega^{\alpha}$ は相隣 る部分系との境界とその他の境界との和であるので,

$$
\Omega^{\alpha}=\omega^{\alpha}+\nu^{\alpha}
$$

で与えられる。物質の出入りは $\omega^{\alpha}$ のみによるので, (2) 式は

$$
d M_{k}^{\alpha} / d t=-\int_{\omega^{\alpha}} \rho_{k} v_{k} d \Omega^{\alpha}+J_{j}^{\alpha} V^{\alpha}
$$

（3）式を考慮すると，

$$
\begin{aligned}
& -\int_{\omega^{\alpha}} \rho_{k} v_{k} d \Omega^{\alpha} \equiv d_{i} M_{k}^{\alpha} / d t \\
& J_{j}{ }^{\alpha} V^{\alpha} \equiv d_{t} M_{k}{ }^{\alpha} / d t
\end{aligned}
$$

とそれぞれ, 添え字 $i, t$ で, 隣接系から流入と蒸発, 液化の相変化による生成に分けることができる。

したがって，

$$
d M_{k}^{\alpha} / d t=d_{t} M_{k}^{\alpha} / d t+d_{i} M_{k}^{\alpha} / d t
$$

と表される。また, 輸送域では相変化は起こらないも のとしているので,

$$
\begin{array}{r}
d M_{k}^{\mathrm{III}} / d t=-\sum_{\alpha=\mathrm{I}}^{\mathrm{II}} d_{i} M_{k}^{\alpha} / d t=0 \\
(k=1,2)
\end{array}
$$

これは，一方の部分系から流出した水素は必ず他方の 部分系に流大することを表している。

つぎに系のエネルギー保存を考えよう。系の運動エ ネルギー $K^{\alpha}$ について次式が成立する。

$$
\begin{array}{r}
d K^{\alpha} / d t=-\int_{\omega^{\alpha}}(1 / 2) \rho v^{2} v d \Omega^{\alpha}=d_{i} K^{\alpha} / d t \\
(\alpha=\mathrm{I}, \text { II })
\end{array}
$$

ここで, $\rho v=\sum_{k=1}^{2} \rho_{k} v_{k}$ であり, $\rho$ は全密度, $v$ は重心 の速度である。部分系IIIについては,

$$
0 \equiv d K / d t=-\sum_{\alpha=1}^{I I} d_{i} K^{\alpha} / d t
$$

が成立する。系における局所エネルギーは次式で与え られる。

Vol. 23 No. 6 (1988)

$$
\begin{aligned}
\delta \rho e / \delta t= & -(\delta / \delta z)\left\{J_{\mathrm{q}}+p v\right. \\
& \left.+\rho\left(u+(1 / 2) v^{2}+g z_{\mathrm{g}}\right) v\right\}
\end{aligned}
$$

ここで, $e$ は全比エネルギー, $J_{q}$ は熱流束, $u$ は比 内部エネルギー，pは压力， $z_{\mathrm{g}}$ は垂㨁座標を表す。 ここで, 粘弹性と外部ポテンシャルの影響を無視し た。比エンタルピー,

$$
h=u+p \rho^{-1}
$$

を用いると，(10)式から部分系の全エネルギーEにつ いて次式を得る。

$$
\begin{aligned}
d E^{\alpha} / d t= & -\int \Omega^{\alpha}\left(J_{q}+h \rho v\right. \\
& \left.+(1 / 2) \rho v^{2} v+\rho v g z_{\mathrm{g}}\right) d \Omega^{\alpha}
\end{aligned}
$$

ここで,

$$
\begin{aligned}
& -\int_{\nu^{\alpha}} J_{\mathrm{q}} d \Omega^{\alpha} \equiv d_{e} Q^{\alpha} / d t \\
& -\int_{\omega^{\alpha}} J_{\mathrm{q}} d \Omega^{\alpha} \equiv d_{i} Q^{\alpha} / d t \\
& -\int_{\omega^{\alpha}} \rho v d \Omega^{\alpha} \equiv \sum_{k=1}^{2} d_{i} M_{k}^{\alpha} / d t \equiv d_{i} M^{\alpha} / d t
\end{aligned}
$$

$$
\begin{aligned}
d_{e} E^{\alpha} / d t= & d_{e} Q^{\alpha} / d t \\
d_{i} E^{\alpha} / d t= & d_{i} Q^{\alpha} / d t+\left(h^{\alpha}+g z_{\mathrm{g}}\right) \\
& \left(d_{i} M^{\alpha} / d t\right)+d_{i} K^{\alpha} / d t
\end{aligned}
$$$$
(\alpha=\mathrm{I}, \mathrm{II})
$$$$
d E^{\mathrm{III}} / d t=-\sum_{\alpha=\mathrm{I}}^{\mathrm{II}} d_{i} E^{\alpha} / d t=-\sum_{\alpha=\mathrm{I}}^{\mathrm{II}}\left(d_{i} Q^{\alpha} / d t\right.
$$$$
+\left(h^{\alpha}+g z_{\mathrm{g}}\right)\left(d_{i} M^{\alpha} / d t\right)
$$$$
\left.+d_{i} K^{\alpha} / d t\right)=0
$$

（9）式を考慮すると,

$$
-\sum_{\alpha=1}^{I}\left(d_{i} Q^{\alpha} / d t+\left(h^{\alpha}+g z_{\mathrm{g}}\right)\left(d_{i} M^{\alpha} / d t\right)\right)=0
$$

となる。(15)式は部分系間のエネルギーの保存を与え る。ここで重力によるエネルギーを無視すると，

$$
-\sum_{\alpha=\mathrm{I}}^{I}\left(d_{j} Q^{\alpha} / d t+h^{\alpha}\left(d_{i} M^{\alpha} / d t\right)\right)=0
$$

となり, 密閉熱サイフォンを力学系として見るときの 基本式となる。

\section{3 エントロピーの生成}

各部分系のエントロピー $S^{\alpha}$ の変化は

$$
\begin{aligned}
d S^{\alpha} / d t & =\int_{V^{\alpha}}(\delta(\rho s) / \delta t) d V^{\alpha} \\
& =-\int \Omega_{\Omega^{\alpha}} J_{t \delta} d \Omega^{\alpha}+\int_{V^{\alpha}} \sigma d V^{\alpha}
\end{aligned}
$$

で表される。ここで, $s$ は比エントロピー, $J_{t s}$ は全エ ントロピー流束, $\sigma$ はエントロピー生成速度を表す。 


$$
J_{t s}=\left(J_{\mathrm{q}}-\sum_{k=1}^{2} \mu_{k} J_{k}\right) / T+s \rho v
$$

ここで, $\mu_{k}$ は成分 $k$ の化学ポテンシャルで, $J_{k}=\rho_{k}$ $\left(v_{k}-v\right)$ である。エントロピー生成に関する項は,

(12)，(14) 式より

$$
\begin{aligned}
\int_{V^{\alpha}} \sigma d V^{\alpha}= & -\sum_{k=1}^{2} \mu_{k}^{\alpha} J_{j}^{\alpha} V^{\alpha} / T^{\alpha} \quad(\alpha=\mathrm{I}, \mathrm{II}) \\
\int_{V} \sigma d V= & -\sum_{\alpha=1}^{\mathbb{I}} \int_{\omega^{\alpha}} J_{t s} d \Omega^{\alpha} \\
= & \sum_{\alpha=1}^{\mathrm{II}}\left(d_{i} Q^{\alpha} / d t+h^{\alpha}\left(d_{i} M^{\alpha} / d t\right)\right. \\
& \left.-\sum_{k=1}^{2} \mu_{k}^{\alpha}\left(d_{i} M_{k}^{\alpha} / d t\right)\right) / T
\end{aligned}
$$

ここで, Euler の式 $\sum_{k=1}^{2} \mu_{k} \rho_{k}=(h-T s) \rho$ を用いた。 そこで,

$$
\begin{gathered}
d_{i} Q^{\alpha} / d t+h^{\alpha}\left(d_{i} M^{\alpha} / d t\right)=j_{\mathrm{q}}{ }^{\alpha}, \\
\left\{h^{\alpha}\left(d_{i} M^{\alpha} / d t\right)=\sum_{k=1}^{2} h_{k}{ }^{\alpha}\left(d_{i} M_{k}{ }^{\alpha} / d t\right)\right\} \\
d_{i} M_{k}{ }^{\alpha} / d t=j_{k}{ }^{\alpha}
\end{gathered}
$$

とおくと, 全系のエントロピー生成 $P_{s}$ は

$$
\begin{aligned}
P_{s} \equiv & \sum_{\alpha=1}^{\text {III }} \int_{V^{\alpha}} \sigma d V^{\alpha} \\
= & \sum_{\alpha=1}^{\mathrm{II}}\left(j_{\mathrm{q}}^{\alpha} / T^{\alpha}-\sum_{k=1}^{2} j_{k}^{\alpha} \mu_{k}^{\alpha} / T^{\alpha}\right. \\
& \left.-\sum_{k=1}^{2} \mu_{k}^{\alpha} J_{i}^{\alpha} V^{\alpha} / T^{\alpha}\right) \geqq 0
\end{aligned}
$$

この場合の熱力学力は部分系境界のみに発生するか ら,

$$
\begin{aligned}
& \triangle(1 / T)=1 / T \mathbf{I}-1 / T \mathrm{I} \\
& \triangle\left(\mu_{k} / T\right)=\mu_{k} \mathbf{I} / T \mathbf{I}-\mu_{k} \mathrm{I} / T \mathrm{I}
\end{aligned}
$$

とおき，(8)，(13)，(14）式を用いると，

$$
\begin{aligned}
P_{s}= & -j_{q} \mathrm{I} \triangle(1 / T)+\sum_{k=1}^{2} j_{k} \mathrm{I} \Delta\left(\mu_{k} / T\right) \\
& -\sum_{k=1}^{2}\left\{\left(J_{j} \mathrm{I} V \mathrm{I}-J_{j} \mathbf{I} V \mathbf{I}\right)\left(\mu_{k} \mathrm{I} / T \mathrm{I}\right)\right. \\
& \left.+J_{j} \mathbf{I} V \mathbf{I} \triangle\left(\mu_{k} / T\right)\right\} \geqq 0
\end{aligned}
$$

いま,

$$
\begin{aligned}
& j_{k} \mathrm{I}-J_{j} \mathbf{I} V \mathbf{I}=j_{k^{\prime}} \\
& J_{j} \mathrm{I} V \mathrm{I}-J_{j} \mathbf{I} V \mathbf{I}=j_{k^{\prime \prime}} \quad(k=1,2)
\end{aligned}
$$

とおくと，

$$
\begin{aligned}
P_{s}= & -j_{\mathrm{q}} \mathrm{I} \triangle(1 / T)+\sum_{k=1}^{2} j_{k^{\prime}} \triangle\left(\mu_{k} / T\right) \\
& -\sum_{k=1}^{2} j_{k^{\prime \prime}}\left(\mu_{k} \mathrm{I} / T \mathrm{I}\right) \geqq 0
\end{aligned}
$$

（23）式をみると, 生成エントロピーは流束と熱力学 カの積の形で与えられている。ここで, 熱流に関して 定常状態が成立している場合を考える。このとき， $T$ と $\triangle T$ は一定であるので,

$$
\triangle(1 / T)=-\triangle T / T^{2}=\text { 一定 }
$$

となる。したがって, 系は物質流， $j_{k^{\prime}}, j_{k^{\prime \prime}}$ が消光 る状態へと非可逆的に変化し， $\Delta \mu_{k}$ と $j_{\mathrm{q}}$ は一定とな る。すなわち, 部分系 Iを出た水素はII で相変化に より液体になり，I で蒸発した水素はII で液化する ことを表している。このことは，(23) 式にそれぞれ の流束と熱力学力との間の線形関係を代入し, 定常状 態ではエントロピーの生成が最小になるということ と, 線形関係の係数に関する Onsager の相反定理を 適用すると，

$$
j_{k^{\prime}}=0, \quad j_{k^{\prime \prime}}=0
$$

が成立し，導かれる。よって，

$$
\begin{aligned}
& d_{i} M_{k}^{\alpha} / d t+d_{t} M_{k}^{\alpha} / d t=0 \\
& \sum_{\alpha=1}^{\mathrm{I}} d_{t} M_{k}^{\alpha} / d t=0
\end{aligned}
$$

一方，系に流入するエントロピーは (17) 式より，

$$
\begin{aligned}
d_{e} S / d t & =-\sum_{\alpha=\mathrm{I}}^{\mathrm{II}} \int_{\nu^{\alpha}} J_{t s} d \Omega^{\alpha} \\
& =\sum_{\alpha=1}^{\mathrm{II}}\left(1 / T^{\alpha}\right)\left(d_{e} Q^{\alpha} / d t\right)
\end{aligned}
$$

定常状態では,

$$
d S / d t=d_{e} S / d t+d_{i} S / d t=0
$$

が成立する。熱流と物質流が独立であるとして，(26) に(25)と（20）を代入すると，

$$
\begin{aligned}
& \sum_{\alpha=\mathrm{I}}^{\mathrm{II}}\left(1 / T^{\alpha}\right)\left(d_{e} Q^{\alpha} / d t+d_{i} Q^{\alpha} / d t\right. \\
& +h^{\alpha}\left(d_{i} M^{\alpha} / d t\right)=0 \\
& \sum_{\alpha=\mathrm{I}}^{\mathrm{II}}\left\{\sum_{k=1}^{2}\left(j_{k}^{\alpha} \mu_{k}^{\alpha} / T^{\alpha}+\mu_{k}^{\alpha} J_{j}^{\alpha} V^{\alpha} / T^{\alpha}\right)\right\}=0
\end{aligned}
$$

が成立する。すなわち, 定常状態では部分系に流入し た熱流は輸送される熱流と等しいこと, 相変化する水 素と輸送される水素流は等しいことが導かれる。

\section{3. 熱力学モデルと自己平衡性}

緒言にも述べたごとく, 密閉熱サイフォン型冷中性 子源は, 冷減速材槽への熱負荷が変動しても冷減速材 槽内の液面が一定に保たれる性質すなわち自己平衡性 を有する。

それでは自己平衡性をもつための条件はなにかを考 えよう。Fig. 2 (b) に示すように理想的な熱サイフォ 


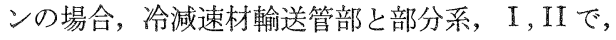

$$
\triangle \mu_{k}=0, \quad A_{j}=0 \quad(\alpha=\mathrm{I}, \mathrm{II})
$$

が成立する。ここで化学親和力 $A_{j}=\sum_{k=1}^{2} \mu_{k}$ を導入し た。これは圧損がゼロで，相変化が平衡の条件であ り, 冷減速材槽で蒸発した水素蒸気は無限の速度で凝 縮器に輸送され, 凝縮器で液化され, 液体水素との間 に相平衡が成り立つことを意味している。見方をかえ れば，輸送管部がない熱サイフォンと見なすことがで きる。このときの全系のエントロピーの生成は，(22) 式から,

$$
P_{s}=-j_{q} \mathrm{I} \triangle(1 / T) \geqq 0
$$

で与えられる。もし系にこのエントロピーの生成を補 償する外部エントロピーの流入があれば，すなわち冷 減速材槽からの流入熱量が増加したとき凝縮器への泠 凍機からの泠熱流入が増加すれば補償されることにな る。この方法は, 外部制御を行って泠減速材槽の温度 と液面を一定保つ方法であり，水素低温系が自己平 衡性をむっているのとは異なる。しかし，この場合は 熱負荷の増加があっても冷減速材輸送管部が理想的な 系の条件を満たしていれば冷減速材槽の温度と液面を 一定に保つことができ，(27) 式の条件が满たされる ように外部からの冷熱の流入を制御すればよい。他の 形式は, 泠減速材槽の温度は少し上昇しても液量は一 定に保つ方策を表している。この場合(16)式は成立し ている，すなわち全系において熱量が保存されている とき, 部分系 I (冷減速材槽) でエントロピーが増加 してもII (凝縮器) で減少すればよい。したがって,

$$
\begin{aligned}
& \delta_{i} S=\left\{\left(\delta_{i} S \mathrm{I} / \delta t\right)+\left(\delta_{i} S \amalg / \delta t\right)\right\} \delta t \geqq 0 \\
& \delta_{i} S \mathrm{I} / \delta t>0, \quad \delta_{i} S \amalg / \delta t<0
\end{aligned}
$$

が満たされることである。Iで液体水素が蒸発すれ ば，I のエントロピーは増加する。II で液化量が増 えれば，II でエントロピーは減少する。I と II を結 合しているのは潜熱であり, II でIからの流入熱量 が増加したとき，IIでの液化潜熱が I での蒸発潜熱に 比べさくなれば液化量が増え, 輸送管が無視される 系では無限の速度でI に輸送されるので，I の液量は 補償されたことになる。害際密閉系に括いては, 蒸発 により系の圧力が増加すれば沸点が上昇し, 水素の潜 熱が小さくなるので，この条件が満たされ，自己平衡 性をもつことになる。また凝縮器の液化能力も, 系の 温度が上昇すれば冷凍機の冷涷能力の増加に比例して 増加するので, II から流出する冷熱の量が增え, こ れからの寄与もある。しかし，これは (29), (30) 式 を満たす過程, すなわち一方の部分系でのエントロピ
一生成を他の部分系で完全に補償するいわゆる負のエ ントロピー生成が生じたといらことではない。時間微 分を・で表し，Iでの $\dot{Q}_{i}$ I の増加量を $\delta \dot{Q}_{i}$ I, II で の凝縮器の液化能力の増加による $\dot{Q}_{i} \mathbb{I}$ の増加量を $\delta \dot{Q}_{i} \mathbb{I}$, 水素の潜熱の減少量を $\delta h \mathbb{I}$, 温度の上昇を $\delta T$ として，(28) 式すなわち (21) 式の第1 項に代入して みると,

$$
\begin{array}{r}
\left(\delta \dot{Q}_{i} \mathbb{I}+\delta h \mathbb{I} \dot{M}_{2} \mathbb{I}\right) /(T \mathbb{I}+\delta T) \\
\geqq \delta \dot{Q}_{i} \mathrm{I} /(T \mathrm{I}+\delta T)
\end{array}
$$

が成立するとき，(28) 式のエントロピーの生成の一 部が補償され，目己平衡性が現れることがわかる。こ れは, “潜熱といら共通のもので熱力学的に結ばれた 二つの部分系において，Iで秩序破壊的な現象が起こ ったときII で秩序形成的なことが補償的な変化とし て起こる” ${ }^{8)}$ 一の例と見なすことができ，自己平衡 性は潜熱を媒介として液化という，エントロピーがー一 見減少する過程が系の温度上昇というエントロピー增 大過程のもとで現れた性質と見ることができる。

\section{4. 結言}

密閉熱サイフォン型冷中性子源を, 非連続熱力学モ デルを用いて非平衡熱力学により解析した。その結 果, 密閉熱サイフォン型冷中性子源の優れた特性であ る自己平衡性の条件ならびに熱力学的意味をエントロ ピーの生成から導くことができた。自己平衡性とは熱 力学的に見たとき, 潜熱といら共通の量で熱力学的に 絬ばれた二つの部分系において，Iの部分系で秩序破 壊的な現象すなわち蒸発が起こったとき, II で秩序 形成的な液化が系の温度上昇といらエントロピー増大 過程のもとで補償的な変化として起こった結果である と位置づけることができた。

\section{参考 文 献}

1) P. Ageron and J. M. Astruc: Bull. Inform. Sci. Tech. 166 (1972) 17

2) 河合 武, 杉本正明, 岡本 朴: 低温工学 15 (1980) 339

3) T. Kawai, et al. : Ann. Rep. Res. Reactor Inst. Kyoto Univ. 13 (1980) 105

4) T. Kawai, et al. : Proc. Int. Conf. on Neutron Physics, Kiev, USSR (1987) to be published

5) M. Utsuro, et al.: Proc. Symp. ICNS '88, Grenoble, July $12-15$ (1988)

6) T. Ebisawa, et al.: Ann. Rep. Res. Reactor Inst, Kyoto Univ. 21 (1988) 1

7) S. R. de Groot and P. Mazur: Non-Equilibrium Thermodynamics, North-Holland Publ., Co., Amsterdam (1963)

8) 高山光男: 物性研究 42 (1984) 145

Vol. 23 No. 6 (1988) 